\title{
Why do firms invest abroad? An analysis of the motives underlying Foreign Direct Investments *
}

\author{
Chiara Franco $^{\dagger} \quad$ Francesco Rentocchini ${ }^{\ddagger}$ \\ Giuseppe Vittucci Marzetti ${ }^{\S}$
}

December, 2008

\begin{abstract}
Although FDI have been at the forefront of economic debate since a long time, economists have not yet developed a unified framework for their investigation. In this paper, we put forward the idea that an essential point to analyze FDI concerns their underpinning motives. Motives are at the core of FDI and FDI are only but one of different alternative means for firms to grasp an opportunity in a foreign country. We discuss the factors that shape the set of available alternatives and analyze those affecting the decision to engage in FDI (internalisation determinants), along with those influencing their localisation (localisation determinants). Starting from Dunning (1993) we put forward a revised taxonomy of FDI motives consistent with this framework resource seeking, market seeking and non-marketable asset seeking. In order to show its practical implications, we survey common empirical issues on FDI showing how our analysis can shed light on seemingly contradictory empirical results.
\end{abstract}

Keywords: FDI determinants; FDI motives; taxonomy; foreign direct investments

JEL Classification: F210; F230; L230; L240

*The authors gratefully acknowledge the helpful comments and suggestions of Andrea "publish-or-perish" Fracasso and participants to the ETSG 2008 Warsaw $10^{\text {th }}$ Annual Conference (September 11-13, 2008) on a previous version of this paper. The usual caveat applies. Francesco Rentocchini and Giuseppe Vittucci gratefully acknowledge the financial support from the Autonomous Province of Trento (Grants 2006: TRACKs and FIC).

${ }^{\dagger}$ Department of Economics, University of Bologna, Strada Maggiore 45, 40125 Bologna, Italy, E-mail:chiara.franco2@unibo.it

${ }^{\ddagger}$ Department of Economics, University of Trento, via Inama 5, 38100 Trento, Italy, E-mail: francesco.rentocchini@economia.unitn.it

${ }^{\S}$ Department of Economics, University of Trento, via Inama 5, 38100 Trento, Italy, E-mail: giuseppe.vittucci@economia.unitn.it 


\section{Introduction}

Foreign Direct Investments (henceforth FDI) have been treated by different streams of literature - management studies, international trade theory, economics of innovation, etc. - and under many perspectives. Notwithstanding, a unified analytical framework of the primitive motives underlying FDI decisions is still missing. Indeed, FDI motivations have been rarely considered as factors that may affect determinants and consequences of FDI. Among the exceptions, Dunning's (1993) contribution, aimed at providing a unified framework for their analysis, is worth mentioning. This work has been the starting point of almost all the following elaboration on the issue.

Nevertheless, Dunning's taxonomy of FDI motives - market seeking, resource seeking, efficiency seeking and strategic asset seeking - is not always internally consistent and we believe there is room for further improvement. The main drawbacks are partly due to its strong commitment to the OLI paradigm (Dunning, 1993), where there is only an ex-post analysis in terms of motives and no consideration of the strategies alternative to FDI compatible with the same underlying motive.

In fact, the motivations behind firms' decisions to grasp an opportunity outside the home country have impacts both on: (i) the actual chosen means - FDI vs. alternative means suitable for the "cherry picking" strategy - (internalisation determinants); and (ii) the choice of the host country (localisation determinants). These two logically distinct steps are always entailed and the final outcome is not necessarily FDI. We identify and analyze the factors influencing FDI choice among the relevant alternatives, together with those affecting the decision of where to locate the activity. We then put forward a new taxonomy of FDI motives consistent with this framework - resource seeking, market seeking and non-marketable asset seeking - and discuss at some length its premises and implications.

The paper is structured as follows. In Section 2, we discuss the logical steps entailed in firms' international strategies, showing why the motives underlying such strategies are essential in order to grasp effects and determinants of FDI. Section 3 critically reviews the literature on FDI motives, emphasising the need of a unified analytical framework. In Section 4, we present our revised taxonomy. In order to show its strong practical implications, in Section 5 we survey some of the empirical issues, showing how the seemingly contradictory results of most of the studies can be actually resolved within our framework. Finally, Section 6 concludes summing up the main results. 


\section{A useful logical framework to analyze firms' international strategies}

Despite all along the paper our main research interest will lie in firms' decision to conduct FDI, in the present Section we step back for a while and concentrate on the general choice of firms to carry out an "international strategy". In some cases, this strategy can lead to an FDI but, in others, other actions (joint venture, outsourcing, etc.) are in fact implemented. The analysis of this process should be preliminary to any analysis of FDI and therefore we put forward a useful logical decomposition of it.

In general terms, the firms' decision making process involved in carrying out an "international strategy" can be depicted as follows. First, firms identify an opportunity which can be grasped outside the home country. It is worth noting that the act of catching the opportunity is the final aim of each firm's action.

Having identified the opportunity, a twofold decision is logically implied in the "cherry picking" strategy:

i) Choice among the relevant alternatives: A first choice has to be made among a set of relevant alternatives. These are all the available different means the firm can exploit in order to seize the opportunity and they strongly depend on the kind of opportunity at stake. For instance, if the main interest for the company is to get access to a foreign market, then both FDI, exports and patent licenses are alternative ways to take advantage of it. On the contrary, if a firm wants to profit from low cost foreign labour, it can resort to either FDI or international outsourcing. Obviously, motives underlying the decision process, e.g. cheap labour or market share, not only affect the basket of alternatives available but also the way factors (e.g. exchange rate or infrastructure) drive the decision among the alternatives. Thus, because we are interested in studying the factors spurring firms to choose FDI, we define them as internalisation determinants. ${ }^{1}$

ii) Location choice: There is a second choice involved in the "cherry picking" strategy: the choice related to the location. Assuming that, at the previous stage, the firm decided to resort to FDI as the relevant alternative to take advantage of a foreign market, the problem of choosing the host country might still be unsolved. We need to underline that, even in this case, the factors affecting such location choice, the so called localisation

\footnotetext{
${ }^{1}$ We have drawn this term from the theory of the firm, even though with a different meaning. As a matter of fact, we do not refer to in a strict sense to the way the firm sets its boundaries (make or buy decision) as it is done in most of the studies (e.g. Coase, 1937; Williamson, 1985) and, especially, in Dunning's (1977) OLI paradigm. Instead, our definition applies to the possible alternatives the same has in order to get access to a foreign country.
} 
determinants, strongly depends on the kind of opportunity the firm wants to grasp.

Although we have identified the process as made up of two logically distinct steps, these can be effectively reversed at times, other times be coexisting or even lacking. Notwithstanding, they should be kept analytically distinct as the factors influencing them can be different and with diverse impacts.

To sum up, we put forward the idea that any proposed classification of FDI is useful only when it is based on the underpinning motives. In fact, a systemic treatment of FDI motives is needed because they turn out to affect two related sets of issues. Firstly, the determinants of FDI activity. ${ }^{2}$ Under this heading we consider both internalisation determinants - factors influencing the probability of choosing FDI among the set of alternative means $^{3}$ - and localisation determinants - factors affecting the choice of the country in which the firm actually invests. Secondly, motives affect the effects of FDI both in the host and home country. In particular, as we will argue later, motives turn out to affect levels and patterns of international trade, FDI contribution to economic development and the amount and direction of productivity spill-overs. As a matter of fact, studying FDI determinants without taking into account motives can lead to estimates that are either non significant or highly-dependent on the sample of countries that has been chosen.

\section{A critical review of the literature on FDI motives}

The issue of FDI motives has not been usually treated as a autonomous field of study and it has crossed different streams of economic literature: international business, international trade theory and the theory of the firm. The most cited taxonomy of FDI motives is the one put forward by Dunning (1993) and built upon his famous OLI paradigm (Dunning, 1977). ${ }^{4}$ This taxonomy distinguishes four kinds of FDI:

\footnotetext{
${ }^{2}$ In line with the past literature, determinants can be defined as "factors that drive FDI behaviour" (Blonigen, 2005, p.383).

${ }^{3}$ For the sake of clarity, it must be stressed that, even when the same alternative is selected for two different orders of reasons, factors influencing the choice of this specific alternative are essentially different. Indeed, the underpinning motives are likely to have a different impact on the direction of the effect or on the characteristic of the same alternative.

${ }^{4}$ According to Dunning, this paradigm should explain why (ownership), where (location) and how (internalisation) a firm becomes multinational. The ownership advantage is the mobile asset (e.g. a patent or a trademark) the firm owns or controls; the location advantage is the exploitation of this asset abroad; the internalisation advantage is the power to directly control the exploitation itself.
} 
i) Resource seeking: the main motive of the firm is the acquisition of particular resources not available at home (natural resources or raw materials) or available at a higher cost (unskilled cheap labour);

ii) Market seeking: firms invest abroad to profit from foreign markets. Various reasons can actually lead to this choice: the need to follow suppliers or customers that have built foreign production facilities; to adapt goods to local needs or tastes; to avoid the costs of serving a market from distance; to have a physical presence on the market in order to discourage potential competitors.

These two categories have been the most cited and debated. In international trade models, they are referred to as respectively vertical and horizontal FDI. In the early analysis by Markusen (1984), the latter derive from the will of avoiding transportation costs or jump tariffs. In particular, firms must decide whether to set up a foreign plant or to serve the market via exports (see also Horstmann, 1992; Brainard, 1997; Markusen and Venables, 1998, 2000). As for the former, they aim at relocating part of the production chain abroad in order to gain from the lower cost of production factors or to gain control over local resources (see, among the others, Helpman, 1984; Slaughter, 2003). These insights have been developed further in the so called "knowledge capital model" by Markusen and Maskus (2002), where a formal model with both motives is tested, and in models like Yeaple (2003) and Grossman et al. (2006), that analyse more complex strategies of international integration with more than two stages of production. Notwithstanding, as for both vertical and horizontal FDI, despite the narrower perspective of analysis and the stronger focus on cost differentials, there is a substantial overlapping with Dunning's distinction of resource vs. market seeking FDI.

The third item of the taxonomy is defined by Dunning as:

iii) Efficiency seeking: FDI that occur when: (i) firms "take advantage of differences in the availability and costs of traditional factor endowments in different countries"; or (ii) they "take advantage of the economies of scale and scope and of differences in consumer tastes and supply capabilities" (Dunning, 1993, p.60).

Economists have sometimes used this category by just referring to this blurred definition. Some authors consider this case very close to the one of resource seeking, because it can be regarded as a way to fragment production, thus gaining from the cheap cost of labour in less developed countries (e.g. Eckel, 2003; Nunnenkamp and Spatz, 2002). Other authors instead emphasise the possible gains from common dispersed activities by exploiting economies of scale and scope, given that firms can diversify their assets (e.g. Bevan and Estrin, 2000; Campos and Kinoshita, 2003; Kinoshita and Campos, 2004). 
Being it as it may, it is important to note that both these uses do not add further motives to market and resource seeking.

In all the cases analysed so far, FDI can generate economic rents through the exploitation of some firms' specific asset. These are usually technological assets produced by $R \& D$ investments that the headquarters of the multinational enterprises (henceforth MNE) transfer to the subsidiaries (Cantwell, 1989; Pearce, 1999). For this reason, they are usually called asset exploiting FDI (Narula and Marin, 2005). ${ }^{5}$

The last category Dunning singles out is:

iv) Strategic asset seeking: FDI aim at acquiring a new technological base, rather than exploiting an existing asset.

This last category does not look perfectly consistent with Dunning's (1977) OLI paradigm. Indeed, in this case there is no previous advantage of the firm investing abroad. This points out that the analysis of motives has not guided the building of the OLI paradigm and that FDI motives are likely to have been only ex-post determined. Moreover, although the definition does not refer to any explicit "strategic" choice, Dunning describes various situations in which, rather than pure asset seeking, strategic considerations are the dominant motives. This proves that the present category is a sort of residual item in which Dunning puts all the cases that do not fit well with the previous three classes. ${ }^{6}$

Following the distinction made by Cantwell and Mudambi (2005) and leaving aside the strategic considerations, FDI belonging to this fourth group are classified under the heading of asset seeking. ${ }^{7}$ This motive has recently attracted a considerable body of theoretical and empirical literature, that can be divided in two strands. The first analyses the international location of R\&D (e.g. Cantwell, 1995; Cantwell and Janne, 1999). Indeed, as argued by Kumar (2001), if one assumes localised knowledge spill-overs, firms engaging in FDI can actually tap into the capabilities available in the host country by locating subsidiaries close to the local leading centres of R\&D (Pearce, 1999; Niosi, 1999). The second strand deals instead with the issue of absorbing technology, where the case of MNE "without advantages" is considered

\footnotetext{
${ }^{5}$ Equivalent expressions are: home base exploiting (Kuemmerle, 1999) and competence exploiting (Cantwell and Mudambi, 2005).

${ }^{6}$ In fact, Dunning (1993) analyses also other minor motives he is not able to insert in any of the four categories previously described. They are classified into three groups: (i) escape investments, i.e. investments made "to escape restrictive legislation or macro-organizational policies by home governments"; (ii) support investment, needed to "support activities of the rest of the enterprise of which they are part" (1993, p.61); and (iii) passive investments, investments closer to portfolio investments, although sharing with FDI some characters of active involvement in firm management.

${ }^{7}$ Equivalent expressions are: home-base augmenting (Kuemmerle, 1999) and competence creating (Cantwell and Mudambi, 2005).
} 
(Fosfuri and Motta, 1999; Siotis, 1999). ${ }^{8}$ Finally, there is also a number of econometric studies testing the asset seeking hypothesis (see, among the others, Kogut and Chang, 1991; Neven and Siotis, 1996; VanPottelsberghe and Lichtenberg, 2001).

But motives have been considered also within the literature on knowledge and productivity spill-overs, where FDI are classified in technology exploitation and technology sourcing and sectorial $\mathrm{R} \& \mathrm{D}$ intensity has been used to test for the possibility of reversed spillover effects (Driffield and Love, 2002, 2007)..$^{9}$

A last stream of literature that has incidentally dealt with FDI motives is the one on location determinants of FDI. In these analysis, the motives are examined ex-post by considering whether certain features of the country might be related to the attraction of FDI characterised by particular motives. Thus, for instance, a rise in market dimension has been associated with a rise in market seeking FDI inflows (Brainard, 1997; Markusen and Maskus, 2002). And the same kind of reasoning has been followed for resource seeking (Carr and Maskus, 2001) as well as efficiency or asset seeking FDI (Nunnenkamp and Spatz, 2002).

\section{A modified motive-based classification of FDI}

The analysis of the previous Section has showed the partial and fragmented way the literature has dealt with FDI motives so far. To the best of our knowledge, Dunning's (1993) analysis is the only systematic taxonomy and it is therefore our starting point. Notwithstanding, the modified version of this taxonomy we propose here is not based on the OLI paradigm, but it comes from the logical steps entailed by firms' international strategies identified and discussed in Section 2. Thus, despite some seemingly apparent similarities, the conceptual framework is radically different.

We classify FDI according to their motives in: resource seeking, market seeking and non marketable asset seeking. In what follows, for each of these items, we discuss the definition and the alternative means the firm has in hand for the cherry picking strategy, along with internalisation and localisation determinants. Table 1 summarises the main results.

\footnotetext{
${ }^{8}$ Strategic aspects of firms' behaviour are considered instead by Bjorvatn and Eckel (2006), who analyse entry strategies of lagging and leading firms.

${ }^{9}$ Within this analytical framework, Driffield and Love (2007) also suggest a taxonomy to disentangle the broad categories of asset exploiting and asset seeking motives by combining two different sets of issues: (i) technology differences, measured by $\mathrm{R} \& \mathrm{D}$ intensity differentials; and (ii) factor costs differences, measured by units of labour.
} 


\subsection{Resource seeking}

Following Dunning $(1993,1998)$, one of the motives for firms to engage in FDI activity goes under the heading of resource seeking (henceforth RS). As Dunning puts it, this should include all the cases where enterprises are "prompted to invest abroad to acquire particular and specific resources at a lower real cost than could be obtained in their home country (if, indeed, they are obtainable at all)." (1993, p.56).

Unlike Dunning, we use the term resource to refer to natural scarce resources and labour, both unskilled and skilled, whereas in Dunning (1993) the term is referred to natural resources, unskilled labour and technological and managerial capabilities. It is important to grasp such differences. On the one side, we do not include technological and managerial capabilities. As we will see later, for the present aim such assets should be more properly viewed as non marketable assets, because they are relevant in affecting FDI decisions only as far as they cannot be directly transferred by means of market transactions. On the other side, we include skilled labour in the present category. Indeed, although FDI aimed at acquiring human capital are usually considered asset seeking FDI (see, for instance, Zanfei, 2000), and thus analysed in relative isolation, the fact that workers' skills can be, although partially, the object of market contracts leads to analogies with the other cases under the present heading. In fact, although the cases of skilled-labour seeking FDI can actually show peculiar features in the degree and patterns of productivity spillover they produce, they show instead characteristics which are quite similar to those of the remaining cases of this category with respect to the relevant alternatives as well as the internalisation and location determinants.

As for the set of the alternative strategies the firm can actually follow, this does not change when the resource to exploit is a natural physical resource or unskilled labour, or when it is instead skilled labour. Indeed, in both cases, in spite of engaging in a FDI, the firm can decide to resort to international trade in intermediates or international outsourcing. ${ }^{10}$

\footnotetext{
${ }^{10}$ The term outsourcing has been used by economist with slightly different meanings. Someone (e.g. Van Long, 2005) uses it mainly referring to international partnerships, thus assuming a minimum level of relation durability. Some others utilise it in all the cases in which firms resort to foreign markets to acquire intermediate inputs (e.g. Feenstra and Hanson, 1999). In this case, the term is therefore just a synonym of international trade in intermediate inputs. Finally, some other economists (e.g. Bhagwati et al., 2004) uses the term outsourcing only referring to the cases in which what it is actually outsourced is service provision. Sometimes the term is used as a synonym of delocalisation or off-shoring, especially within the international trade literature (e.g. Hummels et al., 1998; Glass, 2004).

Drawing on, among the others, Amiti and Wei (2006), the meaning of outsourcing we decided to stick here delimits it with respect to, on the one side, delocalisation or off-shoring, on the other side, vertical FDI. In particular, we use delocalisation (Leamer, 1996) or off-shoring for referring to the international fragmentation of production stages, being it due to international outsourcing or vertical FDI. In the latter case, the production
} 
The analogies still remain with respect to what we called internalisation determinants. Indeed, in all the resource seeking strategies, no matter if the resource at stake is actually a natural one or skilled/unskilled labour, the factors affecting firms' decision to resort to either outsourcing or FDI are mainly those shaping the boundaries of the firm, that is those influencing the "make or buy" decision. In this respect, the results achieved within the theory of the firm turn out to be particularly useful. We mainly refer to the transaction costs theory (Williamson, 1975, 1979, 1996) and the theory of property rights and incomplete contracts (Grossman and Hart, 1986; Hart and Moore, 1990; Hart, 1995). ${ }^{11}$

Thus, for instance, according to the former theory the boundaries of the firms, and thus in the present context the decision to resort to outsourcing instead of FDI, are mainly affected by the intensity of the so called hold-up problem and the level of conflict among transactors. In particular, there should be a negative correlation between the lack of fungibility of assets (asset specificity), and the expected level of outsourcing. Moreover, when present together with specificity, uncertainty is another factor negatively correlated with outsourcing. ${ }^{12}$ In addition, one should take into account the interrelation of each transaction with all the other exchanges. And, finally, transaction costs are usually assumed to be positively related with asset intangibility (e.g. González et al., 2000) and this is therefore another factor positively affecting FDI decision.

According to the theory of property rights and incomplete contracts, firms instead arise because contracts do not provide for every possible situation and the ex post allocation of power (or control) associated with ownership, the so-called residual control rights, is therefore important: firms are the product of a process of optimal allocation of these residual rights. ${ }^{13}$ Within this framework, the conclusion is that we should not expect a monotonic relation between transaction costs and vertical integration degree, but there should be a positive relation only between asset complementarity (Hart,

stage goes outside the country but still remains within the boundaries of the firm, whereas in the former it crosses both the national and the firm boundaries.

${ }^{11}$ Although in the narrower perspective of general equilibrium models, the integration between the theory of incomplete contracts and the analysis of international organisation of production we suggest here is also in Grossman and Helpman (2002, 2005), Antràs and Helpman (2004) and Grossman et al. (2005).

${ }^{12}$ As noted by González et al. (2000), if no specificity exists, there is no conclusive argument to expect a definite correlation between uncertainty and outsourcing in the transaction costs theory.

${ }^{13}$ In particular, this theory assumes that: contracts are incomplete and this in turn generates costs associated with ex post inefficiencies, re-negotiations and specific investments in firm relationships; assets are specific; there are variables that, though observable, are not verifiable from outsiders; property rights give residual rights of control on assets, both material and immaterial, but not on human resources. For a systematic treatment of the theory see, for instance, Hart (1995). 
1995) and vertical integration. ${ }^{14}$

Finally, also with respect to what we called localisation determinants, the similarities among all the cases of RS FDI as previously defined are quite marked. In all these cases, there should be seemingly a negative association between the country actually chosen for the FDI and the real cost (gross of duties and tariffs) of the resource the firm is interested in; a positive association between the former country and the absolute scarcity of the resource on a global scale; and a positive association between the country and the relative productivity of the resource.

\subsection{Market seeking}

A second motive concerning firms' decisions to engage in FDI activities can go under the heading of market seeking (henceforth MS). As discussed in Section 3, this topic has been extensively explored by the literature so far. The main aim of MS FDI is to exploit a foreign market which is of some appeal to the firm, in particular by supplying the market of the host country, or that of adjacent ones, with goods and services.

The main problem underpinning this kind of FDI motive refers to the fact that foreign market to be exploited is not necessarily the market where FDI takes place. Indeed, the FDI can be either in a direct form or in an indirect one. In the first case, the firm is interested in the exploitation of the market of the country hosting the FDI while, in the second, the country where the FDI is directed is just a "platform" from which it is possible to export to the surrounding area. This distinction between exploitation of the host country and what in the literature are called export-platform FDI (e.g. Ekholm et al., 2003) is very important and it must be kept in mind both in the reminder of the present section and when we will discuss findings of the empirical literature (see Section 5).

Under MS, internalisation determinants can be divided in two main sets of factors: (i) factors influencing firms' ability to export goods and services (the issue of tradability); (ii) factors affecting the extent of appropriability of the results of the production process.

The first set of factors relate to particular characteristics of the goods and services, all those that can compromise the possibility of internationally trading them, as well as to all the different costs that hinder trade, hence influencing the degree of tradability of final products. ${ }^{15}$ According to the classical model of Buckley and Casson (1981), exports imply lower fixed

\footnotetext{
${ }^{14}$ There is a recent interesting empirical application by Feenstra and Hanson (2005) that finds some evidence supporting the existence of a relation between firm outsourcing and contractual incompleteness in the case of delocalisation in China.

${ }^{15}$ In general, trade costs can be broadly defined as "all costs incurred in getting a good to a final user other than the marginal cost of producing the good itself (Anderson and van Wincoop, 2004, p.691)".
} 
costs and higher variable costs compared to FDI. In general, although the typologies of trade costs are numerous, in this Section we will concentrate just on some of them, which are deemed as particularly important for the issue at stake, that is policy barriers and transportation/communication costs.

As for the former, these are all the restrictions that the foreign market is likely to impose on its own imports. The typologies of restrictions available can be distinguished in two main areas. On the one hand, there are direct import restrictions which act on the overall volume of imports of the host country. Among these, we find tariffs, import quotas, voluntary export restraints, local content requirements, red-tape barriers and national procurement (Anderson and van Wincoop, 2004). On the other hand, we have indirect import restrictions which are put in action by fostering the overall volume of exports of the host country. In particular, the means available are principally exports subsidies and export credit subsidies.

All of the above mentioned restrictions are positively correlated with the likelihood of the firm to take the decision to carry out market-based FDI. In particular, the firm is likely to decide for FDI as a mean to "jump" over the restrictions imposed on imports by the host country.

As for transport costs, they can be decomposed in direct and indirect ones. The former refer to freight charges and relative insurance on the shipment. The latter include holding, inventory and preparation costs. While transportation costs have a significant impact on the level of tradability of goods, communication costs impact more the extent of tradability of services (Hummels, 2007). Nevertheless, both of them are positively correlated with the decision to carry out a MS FDI. For example, think of a firm facing the decision either to take out an FDI or exporting the products directly to the host country. The higher the costs of delivering the product are, the more likely the firm is to invest directly into the country via FDI.

The second set of internalisation determinants pertains to factors influencing the extent of appropriability of the results of the production process, that is easiness of imitation and patentability issues. The former refers to the set of factors influencing the extent of appropriability of the results of the production process. The more factors other than patents - such as secrecy, the importance of complementary investments, lead-time and a steeper learning curve - are able to protect the technology from easy and quick imitation, the more likely the firm is to invest directly into the host country.

Easiness of imitation is, in turn, influenced by the degree of patentability of a given invention. Both international and national regulations, ${ }^{16}$ along

\footnotetext{
${ }^{16}$ The most important changes in international regulations approved in the last 30 years are: patentability of new technologies such as software and life sciences discoveries, decrease of the patentability requirement and higher protection accorded in courts.
} 
with the efficiency of the patent office, are factors impacting directly on the possibility for the firm to patent a technology in the host country. The level of appropriability patent assures grants the firm with a temporary monopolistic advantage over competitors in the host market, advantage spurring it to invest directly in the host market. Nevertheless, the same firm faces a somewhat different opportunity, that is the possibility to license the patented technology. In this case, the firm might decide for an alternative strategy other than FDI, that is profiting from licenses' revenues, leading to a negative effect on FDI decision. Indeed, the streams of profits coming from licenses are negatively correlated with MS FDI. We can conclude that the overall effect is mixed, depending on which of the two effects - positive for the monopolistic advantage in the host country and negative for the streams of profits from licenses - overcomes the other.

Once the first step of the decision process is carried out, and therefore a MS FDI is chosen as the appropriate means to pick up the opportunity arisen in a foreign country, then the choice of a location is the subsequent logical step to be accomplished. When the main aim of the firm is to enter into the foreign market, localisation determinants should be distinguished between whether they pertain to the decision to enter exactly the market where FDI is done and whether the host country is seen more as an export platform for the markets of neighbouring countries.

In the first case, a factor driving localisation choices is the size of the host country market. In other situations the growth rate of the market is more important than its absolute size. Other important factors are the presence and intensity of both absolute and comparative advantages. All these factors affect positively the decision to localise the MS FDI in a certain host country.

In the second case, differential in characteristics of host country compared to neighbouring ones are the essential factors influencing the decision to direct the FDI in the host country and use it as an export platform. Among the others, differences in norms and regulations, together with those in labour costs taxes are worth stressing.

\subsection{Non marketable asset seeking}

The last motive for a firm to engage in FDI is the acquisition of assets which are not directly transferable through market transactions. Such assets are characterised by the possibility of being exploited only inside the country or in the "local" context where they are created. Indeed, when this characteristic is taken to the extreme, if the firm is willing to access the asset, it is forced to invest in the host country through FDI. We call it non-marketable asset seeking FDI (henceforth NMAS). ${ }^{17}$

\footnotetext{
${ }^{17}$ It is worth noting that the characteristic of non transferability we are referring to can be related to both inner features of the asset as well as to its institutional and normative context. Just to give an example, we may cite the case of Protected Designation of Origin
} 
To start with, these non transferable assets can be externalities from agglomeration economies. In this case, the fact of being close to other firms may play its role in the FDI localisation. In particular, besides the possibility of better linkages with suppliers and customers and the presence of a valuable market of specialised labour, technological spillover effects spur firms to locate close to local firms' clusters. This possibility has been explored by a large strand of literature, although with different approaches, that underlines how this mechanism occurs (e.g. Wheeler and Mody, 1992; Head, 1995; Barrell and Pain, 1999); and the crucial role of agglomeration economies has been emphasised also in the new economic geography (Krugman, 1991; Fujita et al., 2001). In this sense, FDI and agglomeration economies have already been linked in the previous literature, but it has not been well pointed out that the possibility of replicating the same agglomeration economies across borders might not be feasible because spill-overs can be extremely dependent upon the "local" context.

Second, non transferable assets can be related to learning aspects and, in particular, to the access to the organisational capabilities of the firm. These can be considered a "sticky" resource embedded in particular expertise and organising principles. They are generated inside the firm and, because of their high degree of tacitness, they can be hardly communicated and transferred via market transactions (e.g. Zander and Kogut, 1995). Likewise, the presence of valuable technological knowledge built upon some local specific competencies, that are not reproducible in a different setting, can actually represent something that would be lost if transferred across borders. For these reasons, the complexity of the technology embedded in the local context needs close contacts with the owners of the technological base in order to start a process of accumulation.

With respect to the possible strategies which are alternatives to FDI in this case, they are mainly joint ventures (henceforth JV) and acquisition of core personnel. As for the former, firms might enter into partnerships with other firms to have direct access, exploit and absorb the asset into their own production processes. Indeed, JVs give greater opportunity for technological collaboration and technological exchange. The other possibility for firms is having access to the core personnel of the local firm, given that what is mostly needed is not only the local context where the asset is produced, but the people who have the skills to replicate its production process.

As far as internalisation determinants are concerned, establishing a JV will be less likely when the degree of competition in the market is particularly high. As a matter of fact, when the market is highly competitive the possibility for the firm to have access to the specific asset considered will be

(PDO), an expression used to describe foodstuffs that are produced, prepared and processed in a given location using specific local know-how. The final goods cannot be compared to the same final goods eventually produced with the same characteristics in another country, because the context in which they would be produced is obviously different. 
more difficult if the allied firm is in direct competition with the firm itself or with other firms that are part of the local market. This is essentially because the valuable asset will not be easily disclosed to competitors. On the other side, the greater is the degree of transferability of knowledge through direct contact, the higher will be the possibility that foreign firms will enter into the market with a JV. The second alternative considered above is the international acquisition of the core personnel. In this case, the point is that the higher the degree of organisational capabilities inside human resources is, the higher the probability for firms to resort to FDI will be. Indeed, if the competitive advantage of the firm is not embedded in some key personnel, but instead diffused in the firm's overall organising procedure, in order to get the assets it would be better to acquire the firm through a M\&A rather then trying to capture the key personnel.

Finally, as for the localisation determinants, firms will choose the location according to variables mainly related to the local infrastructure. We are not referring only to basic infrastructure (such as a reliable transport system), but also to scientific and high technological infrastructure (like high-quality telecommunication). In particular, the linkages between the scientific infrastructure and the markets are of crucial importance. Other crucial factors are the closeness to the technological frontier of the host country and the technological gap between the home and the host country. Indeed, firms engaging in NMAS FDI will choose the country in order to access technological assets not available elsewhere. Moreover, as stressed in the literature on absorptive capacity (Cohen and Levinthal, 1989), a great technological gap between countries can impinge on firms' possibility to absorb this technological knowledge (for a recent empirical application, see Girma, 2005). Therefore, in this perspective firms are likely to invest in countries/sectors whose technological knowledge is not too far from their own knowledge.

\subsection{Other motives for FDI}

What remains to show is that our classification of the motives underlying FDI is exhaustive, i.e. it exhausts the motives for a firm to engage in a FDI, or at least that the motives not included are indeed residual and do not

alter the overall figure. In so doing, in Section 4.4.1 we will analyze what can be considered the "residual motives" of FDI, whereas in Section 4.4.2 we explain why we decided not to follow Dunning's (1993) taxonomy, thus considering as separate items neither efficiency seeking FDI nor strategic asset seeking FDI. 


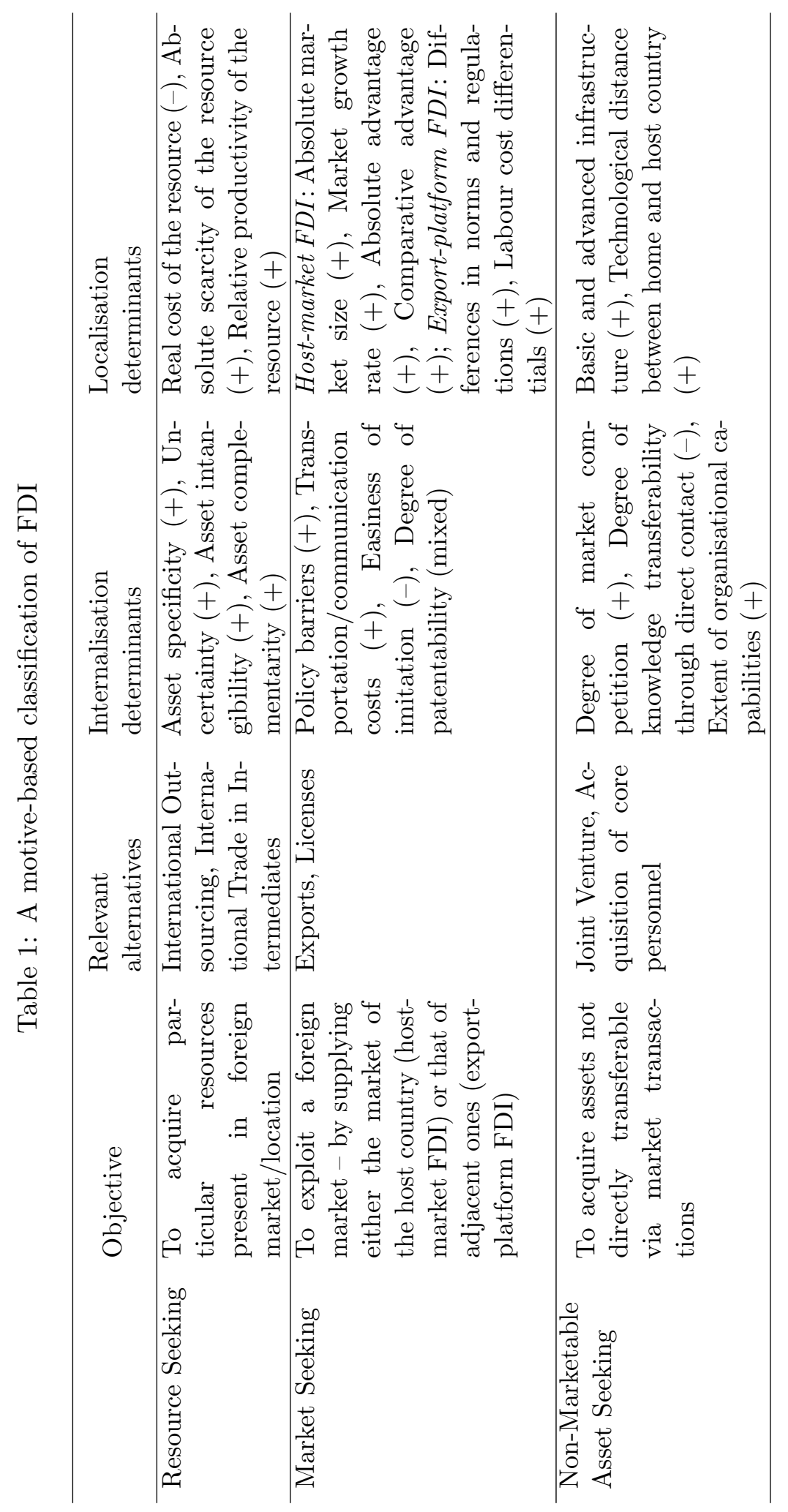




\subsubsection{Residual motives}

With respect to the residual motives, we think the only cases that cannot be subsumed in any of the items of our taxonomy are support investments, as Dunning (1993) terms them, that is FDI whose purpose is mainly "to support the activities of the rest of the enterprise of which they are part." (1993, p.61). These are investments which are highly complementary to other kinds of FDI or outsourcing decisions and, given their inner ancillary nature, they share the character of the main activity they serve. Examples of support investments are trade-related investments of firms, i.e. investments done to manage trade related activities in the host country, such as the purchasing of intermediate inputs in case of resource seeking strategies. They can also equally serve a market seeking strategy by helping managing the relevant information and the network of clients in the target market.

Apart from that, we believe there are no other residual motives left outside, although we should admit that, given the absence of a clear-cut division between FDI and portfolio investments, there could be situations in which the latter share some features with the former. However, we think that in these cases the short term perspective of such investments tends to prevail. First of all, no FDI are usually involved in operations of financial coverage. Second, when acquired firms are actively managed by "new" owners, ${ }^{18}$ whose main aim is actually to gain from short and medium term asset appreciation, there is no relevant change with respect to the determinants, which remain those pertaining to portfolio investments.

Finally, It is worth noting that the problem of distinguishing FDI in a proper sense from speculative foreign investments in real estate, i.e. investments done to gain from the appreciation in land and property prices, is instead mainly related to statistical problems. Indeed, although in theory these investments are not FDI because of their short term perspective, they are nevertheless included in direct investments in national accounts data and cannot be easily distinguished.

\subsubsection{What remains outside?}

We now explain why we left out some of Dunning's categories. First of all, we do not use the efficiency seeking category. Indeed, in line with the logical framework we have identified, efficiency seeking FDI do not represent another mean to reach the goal of exploiting an opportunity in another country. In Dunning's (1993) original analysis as well as in his subsequent studies $(1998 ; 2000)$, the presence of this category is justified by the presence of economies of scale and scope. Indeed, a firm can actually invest abroad through FDI, even though there is an identical firm performing the same functions, whenever there is the possibility to gain from economies of scale and

\footnotetext{
${ }^{18}$ These cases are termed passive investments by Dunning (1993).
} 
scope coming from fixed (indivisible) administrative costs. Notwithstanding, following our logical process, this category does not identify new motives. In fact, efficiency seeking should discriminate only on the possibility of doing outsourcing instead of FDI and this is actually an internalisation choice. ${ }^{19}$

We have struck out also strategic asset seeking FDI. As already argued, this is a residual category which groups FDI not easily explainable within the OLI paradigm. The asset the firm is seeking is not properly identified and the strategic character of the motives, claimed by Dunning as a distinct feature of such category, may be in other categories as well. According to our working hypothesis, this strategic character is indeed the prerequisite of all FDI decisions. Dunning $(1998,2000)$ acknowledges the multiple changes MNEs' activities have undergone because of globalisation, that have force them to rise their asset augmenting activities. However, he does not consider this to be a motive that may generate FDI. And even the new strand of literature on technology sourcing surveyed in Section 3, although clearly takes into account this possibility, does not properly examine the specificity of the asset the firm is trying to acquire. Indeed, it is usually roughly argued that the firm should locate subsidiaries close to firms belonging to innovative sectors or clusters, in order to profit from knowledge spillover. Thus, this literature disregards the analysis of the mechanisms through which the asset is acquired and they turn out to be crucial for the choice of FDI as the actual international strategy.

\section{How motives affect determinants of FDI decision}

In the present Section, we will consider the main determinants of FDI decision addressed by the empirical literature. In particular, we will discuss the effects of exchange rates, trade flows and trade barriers (Blonigen, 2005) on the extent and direction of FDI. We add up to this list by considering two main factors that have drawn the attention of the literature in recent years: institutions and localised knowledge spill-overs. All along the section, most of the effort will be put on showing how our taxonomy of FDI motives is able to better clarify the direction of the effects produced by a certain determinant on the choice and the level of FDI.

As a matter of fact, up to now no definite result has been reached on these issues. By identifying FDI on the basis of their driving motives, we show how to improve our understanding of how selected determinants influence the direction and extent of FDI activity. At the end of the Section, Table 2 summarises the main results.

\footnotetext{
${ }^{19} \mathrm{As}$ a matter of fact, as pointed out in the previous Sections, in empirical studies efficiency seeking FDI are usually subsumed under market or resource seeking FDI.
} 


\subsection{Exchange rates}

Exchange rates are surely one the most studied FDI determinants. The literature has considered three different issues: volatility, levels and expectations.

This paragraph considers the effects of exchange rate, here conceived as the host country currency over the home country currency, on the amount of inward FDI at the country level.

With respect to the extent of exchange rate volatility, both positive (Cushman, 1985; Goldberg and Kolstad, 1995) and negative effects on the amount of inward FDI (Urata and Kawai, 2000; Bénassy-Quéré et al., 2001) have been found, thus pointing out a blurred effect of exchange rate volatility on FDI decision. Notwithstanding, through the lens of our taxonomy, it is possible to get more precise insights on the grounds of the different motives underpinning FDI decision. When FDI is RS, we expect a positive relationship between exchange rate volatility and FDI to arise. In this case, outsourcing is the relevant alternative to FDI and, given that it comprises trade of intermediate goods whose price is more uncertain, the latter option is likely to be preferred. As for MS FDI, the effect is again positive for a similar reason. Indeed, assuming an increasing fluctuation of exchange rates, the price of exports will be surrounded by higher uncertainty, thus spurring firms to prefer FDI. As far as NMAS FDI are concerned, following option theory, we expect the choice to conduct FDI to be procrastinated because of the increasing opportunity for the firm to get higher profits in the future. This points to the existence of a negative relationship between volatility and FDI (Campa, 1993).

As for the level of the exchange rate, the current literature usually identifies a positive relationship between local currency depreciation and FDI (Froot and Stein, 1991; Klein and Rosengren, 1994; Barrel and Pain, 1998). In this case, it is useful to differentiate between localisation and internalisation determinants. As for the former, when the FDI is RS, the effect is positive because we expect to be more difficult for the firm to import if the exchange rate depreciates. In the case of MS FDI, an increase in the exchange rate decreases the cost of acquiring an asset abroad and, at the same time, decreases the nominal profit gained by the FDI activity. That is why the effect is likely to be positive. Nevertheless, reasoning in terms of relevant alternatives, a positive effect, mediated by exports, can arise. Indeed, an increase in exchange rate leads to a decrease in exports, thus reducing the number of available alternatives and hence increasing the likelihood of FDI. As for localisation determinants instead, it is useful to differentiate between perfect and imperfect capital market. In the former case, the effect is nil because of the impossibility to take advantage of internal prices; while, in the latter, we expect a positive effect because the firm may act through prices in order to rise nominal profits. Hence, the resulting effect is positive. Finally, for NMAS, the effect is positive because, in the short run, the price 
of the asset the firm is trying to get access is decreasing and it is convenient not to delay its acquisition. This last effect is the "fire sale" effect identified in the empirical literature (Blonigen, 1997).

A third stream of the empirical literature (Campa, 1993; Goldberg and Kolstad, 1995) has shown that an increase in the expected exchange rate may lead to a reduction of the amount of FDI currently undertaken. According to our taxonomy, this effect will be very negative when the choice is between trade and MS FDI given that spot contracts are the norm; when the choice is between outsourcing and RS FDI the effect is less negative, because of the existence of long-term contracts. As for localisation determinants, once FDI is chosen as the relevant strategy, expected exchange rates do not impact on the level of the FDI because, by definition, all the transfers are made internally to the firm. This is the case for both RS and MS FDI; as regards NMAS, it should be pointed out that the effect is negative because an expected "fire sale" effect is again likely to arise.

\subsection{Institutions}

As for the macro area of institutions, it can be divided in two main fields: social and political issues, such as bureaucracy, corruption and infrastructure; and technological environment, as issues related to intellectual property rights (henceforth IPR).

Most of the recent literature (e.g. Bénassy-Quéré et al., 2007) points at good institutions as the driving force of increasing FDI inflows (Wei, 2000; Globerman and Shapiro, 2002). The first point to be considered is related to infrastructure, which includes for example transports and ICTs. Overall, the presence of better infrastructure positively affects the level of FDI carried out at the firm level. However, as it can be seen in Table 2, while the total effect of a better level of infrastructure is always positive thanks to the impact of localisation determinants, some important differences arise between RS and MS FDI for what pertains to internalisation determinants. In the former case, an increase in the level of infrastructure does not induce a firm to prefer FDI to the relevant alternative, namely outsourcing. This happens because both alternatives might benefit from that, thus cancelling each other. In the latter case, FDI is always preferred to the relevant alternative, i.e. exports, because of the possibility to reap a higher market share. As for NMAS FDI, a positive relationship is assumed, mainly because FDI is preferred to the acquisition of core personnel if better infrastructures is present.

Then, under the heading of enforcement of law, we can find issues such as corruption and bureaucracy. As already mentioned, previous literature found a positive sign concerning both the amount and location of FDI. This is confirmed by our taxonomy in all three cases.

Instead, with respect to $I P R,{ }^{20}$ the effect is more complex. Even at a

\footnotetext{
${ }^{20}$ Despite IPR include a set of different instruments, such as copyright, trademark,
} 
theoretical level, there is no agreement on which is the best regime for IPR in order to attract FDI (e.g. Maskus, 2000): both strong and weak IPR regimes may encourage a firm to serve a foreign country through FDI. In case of strong IPR, the firm is more confident that its asset will not be spread out and FDI should therefore grow. However, being now easier to protect the valuable asset it may also be the case that FDI is displaced by export or licensing. Likewise, in case of weak IPR, FDI may grow because firms now need to protect their assets through internalisation. In terms of our classification, in case of RS FDI, we expect a mild negative effect, mainly because the higher codifiability will lead the outsource to better master the phase of the production process of its own competency. Hence, we expect the level of outsourcing to increase whereas that of FDI to decrease. In case of MS FDI, the direction of the effect is less clear. If we compare FDI to licensing, we may expect both a decreasing level of FDI due to higher profits from license revenues and an increasing level of FDI due to the better protection obtained in the host country market against competitors. However, when the comparison is made between FDI and exports, an increase in the degree of patentability will increase the level of FDI because spill-overs will hurt less firm's profits thanks to the higher level of protection. In general, the overall effect is difficult to disentangle even if, at a good approximation, it can be hypothesised to be mild positive. As for NMAS, if we assume that in the host country there is a non-transferable asset the firm is interested in and assume further that this asset refers, for example, to a production process that, although not entirely transferable through the market, is at least partially patented by some local firms, then we should expect that an increase in the degree of patentability in the host market will discourage, at least partially, the willingness of the firm to conduct FDI.

\subsection{Trade protection}

As for trade protection (Belderbos, 1997; Blonigen et al., 2002), we consider both tariff and non-tariff trade barriers. ${ }^{21}$

Considering RS FDI, the effect should be positive because firms, acting on internal prices, can build a more favourable setting, thus more than offsetting the negative sign due to the tariffs imposed on goods' re-import. In the case of MS, we expect a positive sign because of the tariff-jumping hypothesis: firms will invest through a foreign affiliate in order to avoid the higher price of serving the foreign market through exports. ${ }^{22}$ Instead, in the

\footnotetext{
industrial secret, and so on, here we only refer to patent because this issue covers the great majority of the studies on the topic.

${ }^{21}$ Non-tariff barriers are, for example, particular standards to be met on the characteristics of imported goods or other "red tape" barriers. In the case of non-tariff barriers the empirical studies investigating their effect on FDI decision are very limited due data constraints.

${ }^{22}$ However, in the case of MS FDI as export platform, we should consider the fact that exporting both final and intermediate goods to third countries will be preferred to FDI
} 
case of NMAS, the effect is null because higher tariff barriers do not affect the transfer price of the resource the firm is looking for.

\subsection{Localised knowledge spillovers}

The last determinant we consider is related to the issue of localised knowledge spillovers. This literature considers how a firm localising in a cluster might be characterised by advantages deriving from the knowledge ability to spillover from the neighbouring firms or other organisations (universities and research centres) (e.g. Doring and Schnellenbach, 2006; Audretsch et al., 2004). However, this particular location may lead to both technological and pecuniary externality as well as to higher competition. Even though the technology sourcing literature predicts a positive effect on the choice and the level of FDI, which of the two effects is going to prevail is not clear.

According to our taxonomy, in the case of RS FDI a null effect will arise because we expect the firm located in the home country to rely on the firm that, inside the cluster, is able to produce intermediate goods better. This means that the company has no need to invest via FDI. In the case of MS FDI, the effect is positive because the firm has higher possibilities of rising its productivity (through spillover effect) and therefore selling higher amount of goods in the local market. Finally, for NMAS, the effect is again positive, because through an FDI a firm can get more of the resource it needs and so it can increase its productivity.

\section{Conclusions}

Despite FDI have been at the centre of the analysis since a long time, economics has not yet developed a unified framework for their investigation. Up to now, the only valuable instrument available to sail through the subject is Dunning's (1993) taxonomy which has been extensively used in numerous empirical works on the subject. Notwithstanding, we think that it does not constitute a complete and trustworthy theoretical framework able to guide the researcher through the analysis of the effects and the consequences of FDI. In this paper, we put forward the idea that an essential point in the study of FDI concerns the underpinning motives spurring FDI decision. Indeed, we believe that motives should be at the core of the FDI decision and that FDI is only but one of different relevant alternatives available to grasp an opportunity arising in a foreign country. Moreover, the relationship between motives and the set of alternatives means by which opportunity can be seized is presented. According to that, we show how various factors shape the different set of available alternatives and that, among them, what we named internalisation determinants affect the decision for an FDI strategy.

activity. 
Table 2: FDI determinants classified by motives

\begin{tabular}{|c|c|c|c|c|}
\hline & & Resource seeking & Market seeking & $\begin{array}{l}\text { Non marketable } \\
\text { asset seeking }\end{array}$ \\
\hline \multirow{3}{*}{$\begin{array}{l}\text { Exchange } \\
\text { rates }^{a}\end{array}$} & Volatility & $(+)$ & $(+)$ & $(-)$ \\
\hline & $\begin{array}{l}\text { Exchange } \\
\text { rates }\end{array}$ & $\begin{array}{l}\mathrm{ID}^{b}(=) \\
\mathrm{LD}:^{c}(+)\end{array}$ & $\begin{array}{l}\text { ID: }(+) \\
\text { LD: }(+)\end{array}$ & $(+)$ \\
\hline & $\begin{array}{l}\text { Expected } \\
\text { exchange } \\
\text { rates }\end{array}$ & $\begin{array}{l}\text { ID: }(-) \\
\text { LD: }(=)\end{array}$ & $(-)^{*}$ & $(-)$ \\
\hline \multirow[t]{3}{*}{ Institutions } & Infrastructure & $\begin{array}{l}\text { ID: }(=) \\
\text { LD: }(+)\end{array}$ & $\begin{array}{l}\text { ID: }(+) \\
\text { LD: }(+)\end{array}$ & $(+)$ \\
\hline & $\begin{array}{l}\text { Law } \\
\text { enforcement }\end{array}$ & $(+)$ & $(+)$ & $\begin{array}{l}\text { ID: }(+) \\
\text { LD: }(+)\end{array}$ \\
\hline & $\begin{array}{l}\text { Degree of } \\
\text { patentability }\end{array}$ & $(-)^{*}$ & $(+)^{*}$ & $(-)^{*}$ \\
\hline $\begin{array}{l}\text { Trade } \\
\text { protection }\end{array}$ & & $(+)^{*}$ & $(+)$ & $(=)$ \\
\hline $\begin{array}{l}\text { Localised } \\
\text { knowledge } \\
\text { spillovers }\end{array}$ & & $(=)$ & $(+)$ & $(+)$ \\
\hline * Mild effect & & & & \\
\hline
\end{tabular}

Finally, another set of factors, namely localisation determinants, influence the localisation of the FDI.

On the grounds of this new logical framework, we have critically reviewed the existing literature on the subject, pointing out how our initial concern is actually true, namely that no comprehensive treatment of motives is present there. For this reason, our next step has been to build up a motive-based classification for FDI, distinguishing among three main motives: resource seeking, market seeking and non-marketable asset seeking.

Finally, we have made use of our taxonomy by taking a closer look at the empirical literature dealing with factors affecting FDI decision. It is the case that empirical works has found seemingly contradictory results on the effects of several variables on inward/outward FDI decisions. We have shown how these contradictory outcomes can be consistently reduced thanks to the implementation of our classification which draw the attention on motives and on the effects that the latter have on subsequent FDI decisions. 


\section{References}

Amiti, M. and S. J. Wei (2006). Service offshoring and productivity: Evidence from the United States. Working Paper 11926, International Monetary Fund.

Anderson, J. E. and E. van Wincoop (2004, September). Trade costs. Journal of Economic Literature 42(3), 691-751.

Antràs, P. and E. Helpman (2004). Global sourcing. Journal of Political Economy 112(3), 552-580.

Audretsch, D. B., M. P. Feldman, J. V. Henderson, and J.-F. Thisse (2004). Knowledge Spillovers and the Geography of Innovation, Volume 7, pp. 2713 - 2739. Max Planck Institut fur die Erforschung von Wirtschaftssystemen: Handbooks in Economics.

Barrel, R. and N. Pain (1998). Real exchange rates, agglomeration and irreversibilities: Macroeconomic policy and fdi in emu. Oxford Review of Economic Policy 14 (3), 152-167.

Barrell, R. and N. Pain (1999). Domestic institutions, agglomerations and foreign direct investment in europe. European Economic Review 43, 925934.

Belderbos (1997). Antidumping and tariff jumping: Japanese firms' dfi in the european union and the united states. Weltwirtschaftliches Archiv 133, 419-437.

Bénassy-Quéré, A., L. Fontagné, and A. Lahrèche-Révi (2001). Exchange rate strategies in the competition for attracting foreign direct investment. Journal of the Japanese and International Economies 15 (2), 178-98.

Bénassy-Quéré, A., C. Maylis, and M. T. (2007). Instutional determinants of foreign direct investment. The World Economy 30 (5), 764-782.

Bevan, A. and S. Estrin (2000). Determinants of fdi in transition economies. Working Paper n. 342 Center for New Emerging Market, London Business School.

Bhagwati, J., A. Panagariya, and T. N. Srinivasan (2004). The muddles over outsourcing. Journal of Economic Perspectives 18(4), 93-114.

Bjorvatn, K. and C. Eckel (2006). Technology sourcing and strategic foreign direct investment. Review of International Economics 14 (4), 600-614.

Blonigen, B. A. (1997). Firm-specific assets and the link between exchange rates and foreign direct investment. American Economic Review 87 (3), $447-465$. 
Blonigen, B. A. (2005). A review of the empirical literature on fdi determinants. Atlantic Economic Journal 33, 383-403.

Blonigen, B. A., K. Tomlin, and W. W. Wilson (2002). Tariff-jumping fdi and domestic firms' profits. NBER working paper $902 \%$.

Brainard (1997). An empirical assesment of the proximity-concentration trade-off between multinational sales and trade. American Economic Review 87, 520-544.

Buckley, P. J. and M. Casson (1981, March). The optimal timing of a foreign direct investment. Economic Journal 91(361), 75-87.

Campa, J. M. (1993). Entry by foreign firms in the united states under exchange rate uncertainty. The Review of Economics and Statistics 75(4), 614-622.

Campos, N. and Y. Kinoshita (2003). Why fdi go where it goes? IMF Working Paper Series.

Cantwell, J. (1989). Technological innovations and multinational corporations. Blackwell.

Cantwell, J. (1995). The globalization of technology: what reamins of the product life cycle model? Cambridge Journal of Economics 19, 155-174.

Cantwell, J. and O. Janne (1999). Technological globalisation and innovation centres: the role of technological leadership and location hierarchy. Research Policy 28, 119-144.

Cantwell, J. and R. Mudambi (2005). Mne competence creating subsidiaries mandates. Strategic Management Journal 12, 155-172.

Carr, M. and K. Maskus (2001). Estimating the knowledge capital model of the multinational firms. American Economic Review 91, 693-708.

Coase, R. (1937). The nature of the firm. Economica 4, 386-405.

Cohen, W. M. and D. A. Levinthal (1989). Innovation and learning: The two faces of R\&D. The Economic Journal 99(397), 569-596.

Cushman, D. O. (1985). Real exchange rate risk, expectations, and the level of direct investment. Review of Economics and Statistics 67 (2), 297-308.

Doring, T. and J. Schnellenbach (2006). What do we know about geographical knowledge spillovers and regional growth?: A survey of the literature. Regional Studies 40(3), 375-95. 
Driffield, N. and J. Love (2007). Linking fdi motivation and host economy productivity effects: conceptual and empirical analysis. Journal of International Business Studies 38, 460-473.

Driffield, N. and J. H. Love (2002). Does the motivation for foreign direct investment affect productivity spillovers to the domestic sector? Working Paper RP2002, Aston Business School.

Dunning, J. (1977). Trade, Location of Economic Activity and the Multinational Enterprise: a search for an eclectic approach. London, Macmillan.

Dunning, J. (1993). Multinational Enterprises and the Global Economy. Harlow: Addison-Wesley.

Dunning, J. (1998). Location and the multinational enterprise: A neglected factor? Journal of International Business Studies 29(1), 45-66.

Dunning, J. (2000). The eclectic paradigm as an envelope for economic and business theories of mne activity. International Business Review 9, 163-190.

Eckel, C. (2003). Fragmentation, efficiency seeking fdi and employment. Review of International Economics 11 (2), 317-331.

Ekholm, K., R. Forslid, and J. R. Markusen (2003). Export-platform foreign direct investment. Working Paper 9517, NBER.

Feenstra, R. C. and G. H. Hanson (1999). The impact of outsourcing and hightechnology capital on wages: Estimates for the United States, 1979-1990. Quarterly Journal of Economics August, 907-940.

Feenstra, R. C. and G. H. Hanson (2005). Ownership and control in outsourcing to China: Estimating the property-rights theory of the firm. Quarterly Journal of Economics May, 729-761.

Fosfuri, A. and M. Motta (1999). Multinationals without advantages. Scandinavian Journal of Economics 101, 617-630.

Froot, K. A. and J. Stein (1991). Exchange rates and foreign direct investment: an imperfect capital markets approach. Quarterly Journal of Economics 106 (4), 1191-1217.

Fujita, M., P. R. Krugman, and A. J. Venables (2001). The Spatial Economy: Cities, Regions, and International Trade. Cambridge: MIT Press.

Girma, S. (2005). Absorptive capacity and productivity spillovers from fdi: A threshold regression analysis. Oxford Bulletin of Economics and Statistics 67(3), 281-306. 
Glass, A. J. (2004). Outsourcing under imperfect protection of intellectual property. Review of International Economics 12(5), 867-884.

Globerman, S. and D. Shapiro (2002). Global foreign direct investment flows : The role of governance infrastructure. World Development 30(11), $1899-1919$.

Goldberg, L. and C. Kolstad (1995). Foreign direct investment, exchange rate variability and demand uncertainty. International Economy Review 36 (4), 855-873.

González, D. M., B. Arrunada, and A. Fernández (2000). Causes of subcontracting: Evidence from panel data on construction firms. Journal of Economic Behavior \&S Organization 42, 167-187.

Grossman, G. and E. Helpman (2005). Outsourcing in a global economy. Review of Economic Studies 72, 135-159.

Grossman, G. M. and E. Helpman (2002). Integration versus outsourcing in industry equilibrium. The Quarterly Journal of Economics 117(1), $85-120$.

Grossman, G. M., E. Helpman, and A. Szeidl (2005). Complementarities between outsourcing and foreign sourcing. The American Economic Review 95(2), 19-24.

Grossman, G. M., E. Helpman, and A. Szeidl (2006). Optimal integration strategies for the multinational firm. Journal of International Economics 70, $216-238$.

Grossman, S. and O. Hart (1986). The costs and benefits of ownership: a theory of vertical integration. Journal of Political Economy 94, 691-719.

Hart, O. (1995). Firms, Contracts and Financial Structure. Oxford: Clarendon Press.

Hart, O. and J. Moore (1990). Property rights and the nature of the firm. The Journal of Political Economy 98, 1119-1158.

Head, Ries, S. (1995). Agglomeration benefits and location choice: evidence from japanese manufacturing investments in the united states. Journal of International Economics 38, 223-247.

Helpman, E. (1984). A simple theory of international trade with multinational corporations. Journal of Political Economy 92(3), 451-471.

Horstmann, I. (1992). Endogenous market structures in international trade. Journal of International Economics 32, 109-129. 
Hummels, D. (2007). Transportation costs and international trade in the second era of globalization. The Journal of Economic Perspectives 21(24), $131-154$.

Hummels, D., D. Rapoport, and K.-M. Yi (1998). Vertical specialization and the changing nature of world trade. Federal Reserve Bank of New York Economic Policy Review 4, 79-99.

Kinoshita, Y. and N. F. Campos (2004). Estimating the determinants of foreign direct investment inflows: How important are sampling and omitted variable biases? Discussion Papers 10, BOFIT - Institute for Economies in Transition.

Klein, M. W. and E. Rosengren (1994). The real exchange rate and foreign direct investment in the united states: Relative wealth vs. relative wage effects. Journal of International Economics 36 (3/4), 373 - 389.

Kogut and Chang (1991). Technological capabilites and japanese foreign direct investment in the united states. Review of Economic and Statistics 73 (3), 401-413.

Krugman, P. (1991). Geography and Trade. Cambridge, Mass-Louvain.

Kuemmerle, W. (1999). The drivers of foreign direct investments into research and development: an empirical investigation. Journal of International Business Strategy 30, 1-24.

Kumar, N. (2001). Determinants of location of overseas r\&d activity of multinational enterprises: the case of us and japanese corporations. Research Policy 30, 159-174.

Leamer, E. E. J. L. (1996). International Trade Theory:The Evidence, Volume 3. Amsterdam: North-Holland.

Markusen and Venables (1998). Multinational firms and new trade theory. Journal of International Economics 46, 183-203.

Markusen, J. K. and A. J. Venables (2000). The theory of endowment, intraindustry and multinational trade. Journal of International Economics 52, 209-234.

Markusen, J. R. (1984). Multinationals, multi-plant economies, and the gains from trade. Journal of International Economics 16(3-4), 205-226.

Markusen, J. R. and K. Maskus (2002). Discriminating among alternative theories of the multinational enterprise. Review of International Economics 10, 694-707. 
Maskus, K. (2000). Intellectual property rights and foreign direct investment. University of Adelaide, Centre for International Economic Studies, Policy Discussion Paper 0022. Adelaide.

Narula, R. and A. Marin (2005). Exploring the relationship between direct and indirect spillovers from FDI in argentina. MERIT Research Memoranda 2005-024, Maastricht Economic Research Institute on Innovation and Technology.

Neven, D. and J. Siotis (1996). Technology sourcing and fdi in the ec: an empirical evaluation. International Journal of Industrial Organization 14, $543-560$.

Niosi, J. (1999). The internationalization of industrial $r \& d$ : from technology transfer to the learning organization,. Research Policy 28, 107-117.

Nunnenkamp, P. and J. Spatz (2002). Determinants of fdi in developing countries: has globalization changed the rules of the game? Transnational Corporations 11(2), 1-34.

Pearce, D. (1999). Decentralised r\&d and strategic competitiveness: globalised approaches to generation and use of technology in multinational enterprises (mnes). Research Policy 28, 157-178.

Siotis, J. (1999). Foreign direct investment strategies and firms' capabilities. Journal of Economics and Managment Strategy 8, 251-270.

Slaughter, M. J. (2003). Host country determinants of us foreign direct investments into europe. In Foreign Direct Investments in the Real and Financial Sector of Industrial Countries. Herrman and Lipsey (Springer).

Urata, S. and H. Kawai (2000). The determinants of the location of foreign direct investment by japanese small and medium-sized enterprises. Small Business Economics 15 (2), 79-103.

Van Long, N. (2005). Outsourcing and technology spillovers. International Review of Economics 63 Finance 14 (3), 297-304.

VanPottelsberghe, d. 1. P. B. and F. Lichtenberg (2001). Does foreign direct investment transfer technology across borders? Review of Economics and Statistics 83 (3), 490-497.

Wei, S. (2000). How taxing is corruption on internal investors? The Review of Economics and Statistics 82(1), 1-11.

Wheeler, D. and A. Mody (1992). International investment location decisions: the case of us firms. Journal of International Economics 33, 57-76. 
Williamson, O. E. (1975). Markets and Hierarchies: Analysis and Anti-trust Implications: A Study in the Economics of Internal Organization. New York: Free Press.

Williamson, O. E. (1979). Transaction-cost economics: the governance of contractual relations. Journal of Law and Economics 22, 233-261.

Williamson, O. E. (1985). The Economic Institution of Capitalism. New York, Free Press.

Williamson, O. E. (1996). Economics and organization: A primer. California Management Review 38(2), 131-146.

Yeaple, S. R. (2003). The complex integration strategies of multinationals and cross country dependencies in the structure of foreign direct investment. Journal of International Economics 60, 293 - 314.

Zander, U. and B. Kogut (1995). Knowledge and the speed of trasnfer and imitation of organizational capabilities: an empirical test. Organization Science 6 (1), 76-92.

Zanfei, A. (2000). Transnational firms and changing organization of innovative activities. Cambridge Journal of Economics 5, 515-554. 